\title{
NAGYSZILÁRDSÁGÚ ALUMÍNIUMOK ALAKÍTHATÓSÁGÁNAK ELEMZÉSE
}

\author{
Gál Viktor
}

\begin{abstract}
Absztrakt: Az autóipari anyagok és technológiák fejlesztését, az utóbbi néhány évtizedben, alapvetően befolyásolták az egyre szigorúbb környezetvédelmi előirások. Ezen törekvés kielégítésének egyik lehetősége a jármüvek tömegének redukálásával elérhetö károsanyag kibocsájtás csökkenése. A tömegcsökkentés viszont nem járhat együtt a biztonsági elvárások csökkenésével, ezért a felhasznált anyagok szilárdságát növelni kell. Az alumínium, az acélhoz viszonyított kisebb sürüsége által, megoldást jelenthet a tömegcsökkentés tekintetében. Az utasbiztonsági elöírások miatt azonban, ezen a területen csak a nagyszilárdságú ötvözött alumínium lemezek jöhetnek szóba melyeknél a nagy szilárdsági tulajdonságokhoz viszonylag korlátozott alakíthatósági tulajdonságok tartoznak. Ez a kis alakváltozó képesség komoly müszaki kihívás elé állítja a karosszéria elemek alakadásával foglalkozó mérnököket. Publikációmban ezen ellentmondás feloldására kifejlesztett ún. $\mathrm{HFQ}^{\mathrm{TM}}$ eljárás bemutatását tüztem ki célul.
\end{abstract}

\begin{abstract}
In the past 10 years the developments of automotive materials and technologies have been influenced by the environmental regulations. Reducing the mass of vehicles is important to reduce the carbon dioxide emission. In order not to break the safety standards with the mass reduction, the strength of the used materials should be increased. The density of aluminium alloys is lower than that of steels, which is positive for weight reduction. In order not to break the safety standards with the mass reduction, the strength of the used aluminium alloys should be increased, therefore the modern alloys have higher strength. However, due their different alloying elements and the rigid disperse precipitates phase they create, the ductility of these materials is not so good. The bad formability is a serious technical challenge for automotive engineers. Because of this, the objective of this paper is to present the newest $\mathrm{HFQ}^{\mathrm{TM}}$ process that solve this problem.
\end{abstract}

Kulcsszavak: alumínium, $\mathrm{HFQ}^{\mathrm{TM}}$, tömegcsökkentés, melegalakítás, alakíthatóság, alakítási határgörbe

Keywords: aluminium, $\mathrm{HFQ}^{\mathrm{TM}}$, mass reduction, warm forming, formability, forming limit diagram

\section{Bevezetés}

$\mathrm{Az}$ autóipari anyagok és technológiák fejlődését, az utóbbi néhány évtizedben, alapvetően az egyre szigorúbb környezetvédelmi elöírások befolyásolták. Az Európai Unió több körben direktívákat határozott meg, hogy a klímaváltozásért leginkább felelős $\mathrm{CO}_{2}$ kibocsátást, két lépésben 2015-re 20\%-kal 2030-ra 40\%-kal redukálják az 1990-es kibocsájtási mértékhez képest. Egy 2016-os EU-s tanulmányban vázolt állapotot szemléltet az 1. ábra (Climate Action, 2016).

$\mathrm{Az}$ üzemanyag felhasználásnak, és ezzel a károsanyag kibocsátásnak a csökkentésére több módszert dolgoztak ki. A meghajtás oldaláról a start-stop motorok, a hibrid, illetve elektromos autók piacon való megjelenése jelentős elörelépést jelentett a célok elérése érdekében. A közlekedésböl adódó légszennyezés redukálásának másik lehetséges módja a jármüvek tömegének csökkentése, ami nem járhat együtt a biztonsági elvárások csökkenésével, ezért a felhasznált anyagok szilárdságát növelni kell. A szilárdságnövelés azonban az anyagok alakíthatósági jellemzőit drasztikusan rontja. 


\section{1. ábra: Az előre tervezett károsanyag kibocsátás csökkenése}

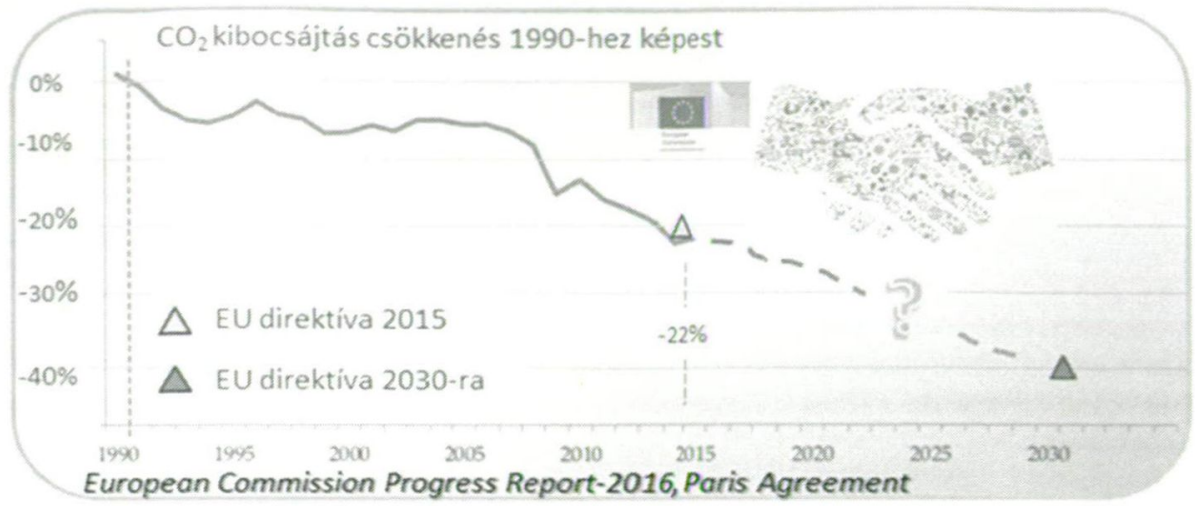

Forrás: European Commission Progress Report-2016 Paris Agreement (Climate Action, 2016)

Mivel acélok esetében a technológiai újításokkal már nem lehet további előrelépést elérni, ezeket a kisebb sürüségủ alumíniummal helyettesítve próbálják az autók tömegét tovább mérsékelni. Az utasbiztonsági elöírások miatt azonban, ezen a területen csak a nagyszilárdságú alumínium lemezek jöhetnek szóba. Az elvárt szilárdsági tulajdonságok eléréséhez viszont nagy mennyiségü ötvöző szükséges, melyek bevitele rossz alakíthatósági tulajdonságokhoz vezet, komoly müszaki kihívások elé állítva a technológus mérnököket.

\section{A HFQ ${ }^{\mathrm{TM}}$ technológia bemutatása}

A korszerü autóipari alumínium alapanyagok alakíthatóságát alapvetően a bennük található ötvözők, illetve az ezek hatására létrejövő rideg diszperz kiválások rontják. Az alakváltozási képesség csökkenése oly mértékü, hogy már az egyszerü geometriai kialakítással rendelkező alkatrészeknél is fennáll az alakítás során a repedés veszélye, valamint a nagymértékü visszarugózás. Mivel a hőmérséklet növelésével az alakváltozási tulajdonságok javulnak, a probléma megoldására egy melegalakítási folyamatot - $\mathrm{HFQ}^{\mathrm{TM}}$ - fejlesztett ki közösen az Impression Technologies és az Imperial College London (Wang et al., 2008). A HFQ ${ }^{\mathrm{TM}}$ (Solution heat treatment, Forming and in-die Quenching) egy olyan folyamat, amely kombinálja az alakítás technológiáját a hőkezeléssel egy müveleten belül. Ez a módszer lehetővé teszi, hogy komplex bonyolult geometriai alakot adjunk az egyébként nehezen alakítható nagyszilárdságú alumínium-ötvözeteknek.

A folyamat első lépése, hogy a lemezt az ötvözők oldódási hőmérsékletére hevítik (SHT). Ez a hőmérsékletközlés feloldja az ötvözőket, amelyek így beépülnek az eredeti alumínium mátrixba ezzel túltelített szilárd oldatot (SSSS) hozva létre, amely már jól alakítható. Az oldó izzítás után a lemezt hideg sajtoló szerszámok közé helyezzük, és a kívánt geometriai alakra alakítjuk. Az oldódási hőmérsékletre hevített lemeznél a hideg szerszámokkal való érintkezés hatására nagy sebességü, jelentős hőelvonás jön létre, ez teszi lehetővé a felhevítés utáni homogén szilárd oldat „,befagyasztását” ezzel fenntartva a kedvező alakíthatósági tulajdonságokat. A 
folyamat végén egy több órás, mesterséges öregítés következik, amely biztosítja, hogy a már elkészült darab visszanyerje eredeti szilárdságát. $\mathrm{A} \mathrm{HFQ}{ }^{\mathrm{TM}}$ folyamatot sematikusan a 2. ábra szemlélteti (Raugei et al., 2014)

\section{2. ábra: $\mathbf{A} \mathbf{H F Q}{ }^{\mathrm{TM}}$ folyamat sematikus ábrázolása}

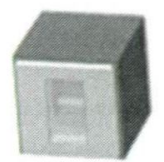

1.) Hevítés oldódási hômérsékletre (SHT)

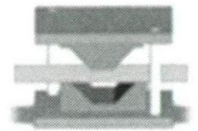

2.) Alakítás hideg szerszámok között

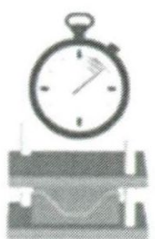

3.) Gyors hütés a szerszámban

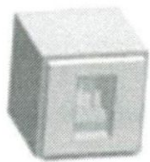

4.) Mesterséges öregités

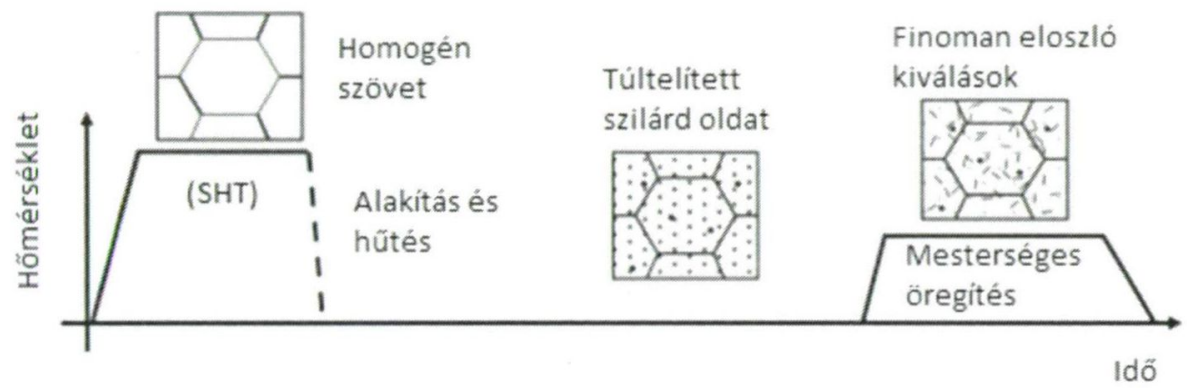

Forrás: Raugei et al. (2014)

A HFQTM folyamatnak egyedülállósága és előnyei mellett meg kell említeni legnagyobb hátrányát is, vagyis a szilárdság visszanyerése érdekében történő több órás hőkezelést, ami miatt kizárólag kissorozatgyártásban illetve egyedi gyártásban alkalmazható pillanatnyilag. A HFQTM technológia kulcsfontosságú, jelenleg is fejlesztés alatt álló elemei az alkalmazott hevítési hỏmérséklet és az ehhez tartozó hőntartási idő.

Jelenleg az autóiparban mindennapos gyakorlattá vált a technológiai és szerszámtervezésben a különféle célterületre orientált numerikus, a technológiai folyamatot virtuális térben modellező szoftveres alkalmazások használata. Ezekben az autóiparban továbbra is jelentős hányadot kitevő hideg képlékenyalakítási folyamatok megfelelő pontossággal elemezhetők. Célként merült fel, hogy az új HFQTM technológia elterjedését is segítené, ha hasonló módon lehetne a technológiai folyamatot vizsgálni a már elterjedt szoftverekben. Ezért jelen publikációmban, ennek nehézségeit tárgyalom.

\section{A HFQ ${ }^{\mathrm{TM}}$ numerikus modellezésének anyagparaméterei}

$\mathrm{Az} \mathrm{HFQ}^{\mathrm{TM}}$ technológiai modellezését több kutató, több publikációban tárgyalta az utóbbi években (Fakir et al., 2014; Mohamed et al., 2014; Gao, 2017) 
Ahhoz, hogy az előző fejezetben ismertetett technológia megjelenhessen a mindennapi gyártásban szükséges, hogy a célorientált szoftverekben is képesek legyenek a melegalakítási folyamatok pontos és kiértékelhető modellezésére. A klasszikus hidegalakítási folyamatok modellezéséhez szükséges anyagparamétereket, egy az iparban eredményesen alkalmazott célszoftver tekintetében az 3. ábra szemlélteti.

\section{3. ábra: Hidegalakítás szimulációjához szükséges paraméterek AutoForm-ban}

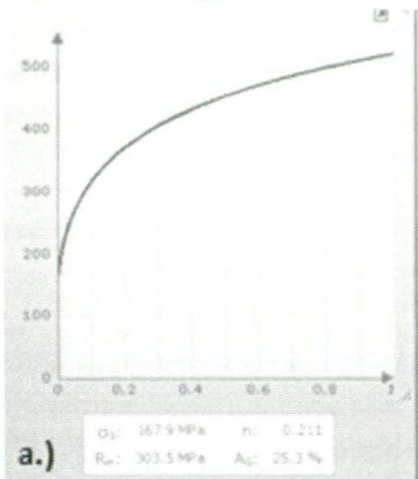

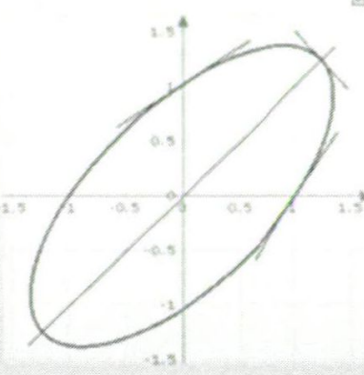

b.)

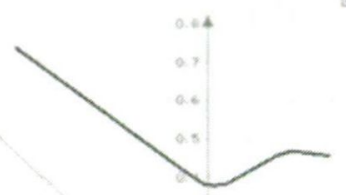

c.)

Forrás: AutoForm^R6

$\mathrm{Az}$ 3. ábra a.) részén a folyási görbe látható, amelyeket jellemzően a hőmérsékletmező illetve az alakváltozási sebesség befolyásol. A 3. ábra b.) részén a folyási határfelület azaz Yield-surface látható, amely megfogalmazza a folyási feltételeket, amelyek meghatározásához szükség van az anizotrópia tényezőre, amely szintén hömérsékletfüggő. A 3. ábra c.) része az alakítási határgörbét mutatja be, mely az előzőekhez hasonlóan függ a hőmérséklet- és alakváltozási sebesség mezőtől. A bemutatott görbék felvétele az újrakristályosodási hőmérséklet alatt nem okoz problémát, a mindennapos gyakorlat részét képzik. Vizsgáljuk meg, milyen kihívásokkal nézünk szembe, ha ezeket a bemeneti anyagparamétereket azok hőmérséklet és alakváltozási sebesség függésükkel akarjuk meghatározni.

\subsection{Melegszakító vizsgálat}

A szimulációk első bemeneti anyagparamétere a folyási görbe, amely megadja, hogy az anyag hogyan keményedik, hogyan viselkedik a bevitt alakváltozás hatására. A folyási görbét jellemzően a szakító diagramokból származtatják. A GLEEBLE fizikai szimulátor alkalmas melegszakító vizsgálatok elvégzésére is, azonban $\mathrm{HFQ}^{\mathrm{TM}}$ körülmények közötti alkalmazása során több nehézséggel is számolni kell. A GLEEBLE fizikai szimulátor a befogópofák közé rögzített próbatestet ellenálláshevítés útján hevíti, majd elszakítja. $\mathrm{A} \mathrm{HFQ}^{\mathrm{TM}}$ folyamat helyes reprodukálásához a szakítópróbatest egész vizsgálati hosszán homogén hőmérsékletüre kell hevíteni. Az ellenállás hevítés sajátossága, hogy a próbatest közepétől kifelé egy inhomogén hőmérséklet eloszlást hoz létre, ami az 
anyagparaméterek meghatározásában nehézségeket okoz (Zhang et al., 2010). Ezért egy lehetséges megoldásként merült fel a tömör rézből készített befogópofák kiváltása egy rosszabb hőelvonási tulajdonságokkal rendelkező anyaggal (korrózióálló acél) -amelynek továbbá a geometriai kialakítását tekintve a kisebb felületen történő érintkezéssel- a hőelvonás tovább csökkenthető. Ezzel befogópofa kialakítással kedvezően lehet befolyásolni a próbatest hossza mentén a hőmérsékletet homogénnek tekinthető hosszát (Nan et al., 2016). Az alakváltozási mértékek mérése az inhomogén hőmérséklet miatt további nehézségként jelentkezik, de ennek lehetséges megoldásaira terjedelmi korlátok miatt ebben a publikációmban nem térek ki.

Amennyiben megoldjuk a folyási görbék emelt hömérsékleten történő felvételét, újabb akadályt jelent a görbék célorientált szoftverekbe (pl.: AutoForm) való beillesztése. Az AutoForm^^^7 verziójában a melegalakítás szimulációjának ezen anyagparaméterét folyási görbe- mátrixszal adhatjuk meg (Manach et al., 2016). Ahogy említettem, a folyási görbék alakváltozási sebesség, illetve hőmérsékletfüggők, tehát egy adott hőmérséklethez több alakítási sebesség mellett kell görbét felvennünk ahhoz, hogy azokat az 4. ábrán szemléltetett mátrixba illesztve tudjuk majd a programba integrálni.

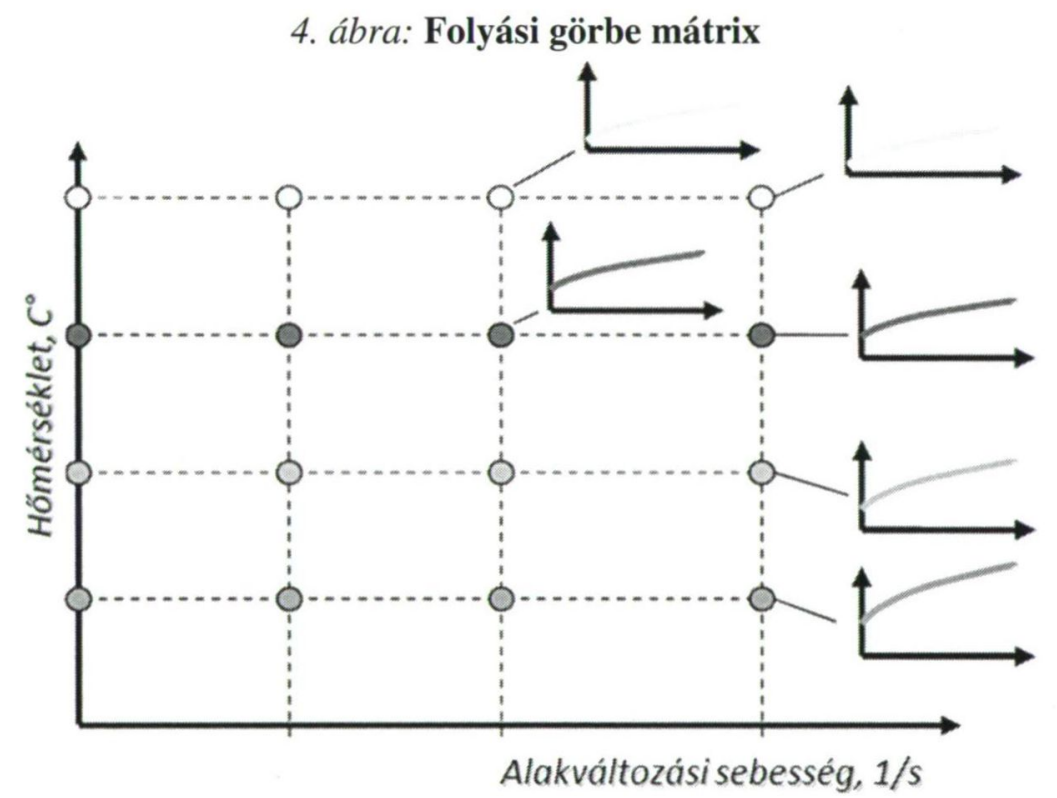

Forrás: Manach P, Coer J, Jégat A, Laurent H, Yoon J (2016) 0

Ennek a mátrixnak a bevitele biztosítja, hogy bonyolultabb alak képzése esetén, ahol összetett, pontonként változó alakítási sebesség, illetve ugyanígy változó hőmérsékletmező van, a program kezelni tudja az anyagra jellemző alakváltozási keményedést, vagyis az anyag viselkedését. 


\subsection{Folyási határfelület}

A folyási határfelület (Yield-surface) adja meg, hogy a feszültségek milyen kombinációjának hatására indul meg a képlékeny alakváltozás (Lukács, 2014). A görbét leginkább a hőmérséklet függvényében változó anizotrópiatényező befolyásolja. Amennyiben a kívánt hömérsékleteken az általános $0^{\circ}-45^{\circ}-90^{\circ}$ fokhoz tartozó anizotrópia értékeket bevisszük, az Autoform^ ${ }^{\wedge} \mathrm{R} 7$ ez alapján és a már előzőekben bemutatott folyási görbe -mátrix segítségével származtatja a különböző hőmérsékletekre vonatkoztatott folyási határfelületeket.

\subsection{Alakítási határgörbe (FLC)}

Az alakítási határdiagramm (FLD) egy elterjedt és a technológus mérnökök számára az egyes alakítási sajátságokat is ábrázoló diagram. A diagramot és a felvételéhez szükséges berendezést szemlélteti az 5. ábra.

\section{5. ábra: Alakítási határdiagram és a vizsgálóberendezés}
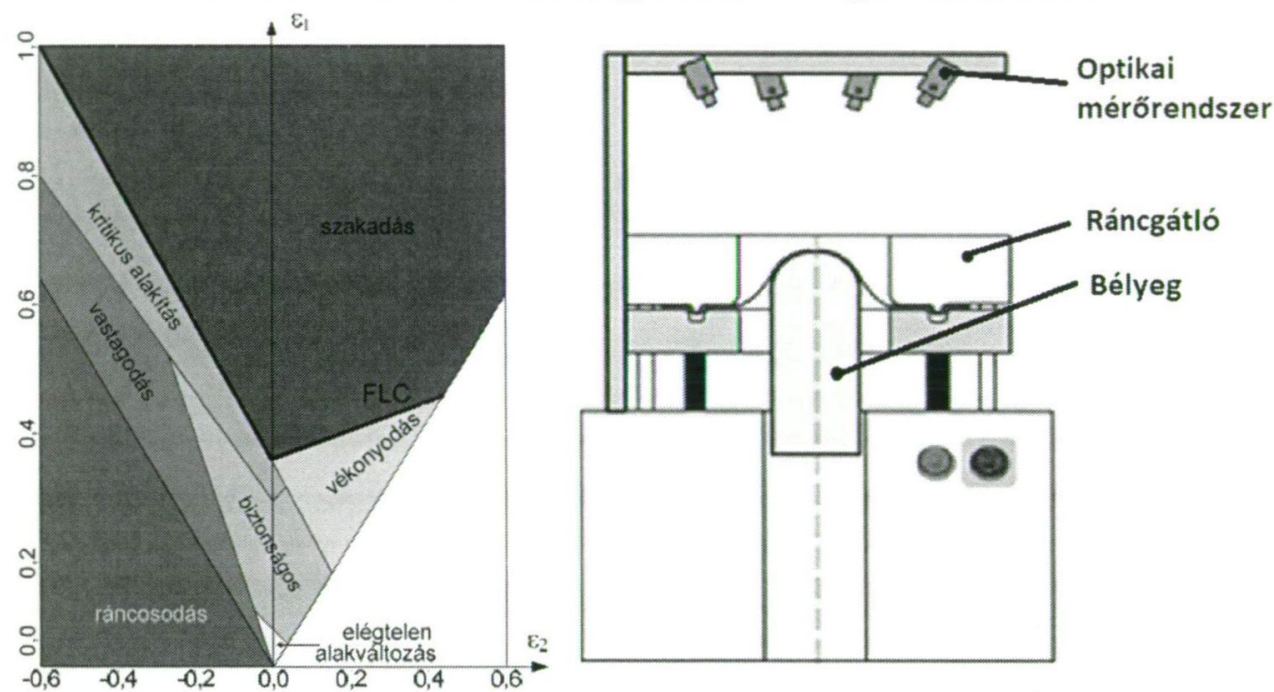

Forrás: Kovács (2012)

Az FLD a fóalakváltozások függvényében ábrázolja az alakváltozási határállapotokat. A diagram legfontosabb része az alakítási határállapotot meghatározó görbe, vagyis az alakítási határgörbe (FLC). Ez a görbe mondja meg, hogy mekkora és milyen alakváltozások bekövetkezése után keletkezik és kezd el terjedni repedés az anyagban (Kovács, 2012). A diagram felvételére több kidolgozott módszer is létezik hidegalakítás esetére (ISO 12 204-1:2008). Ezzel ellentétben a melegalakítás vizsgálata több akadályt is felvet. Az egyik ilyen a homogén hőmérsékletmező létrehozása. A homogén hőmérséklet megvalósítható lenne, ha az egész vizsgálóberendezést egy adott kemencében hevítenénk fel összes alkatrészével, illetve a próbatesttel együtt (Shao et al., 2016), de ezt rendkívüli költségek miatt nem lehetne alkalmazni széles körben. Az FLC görbe felvételéhez 
szükségünk van egy optikai mérörendszerre, amely a próbatestek felületére felvitt hálót (jellemzően hőálló festékkel és szitanyomással, vagy elektrokémiai hálózással készül) érzékeli és az alakítás során folyamatosan rögzíti. Amennyiben ezt a mérőberendezést a kemencén kívül helyezzük el, a felvételek minősége romlik, esetleg kiértékelhetetlenné válnak.

$\mathrm{Az}$ egész vizsgálat kemencében történő lefolytatásával szemben, költséghatékonyabb megoldás, a vizsgálóberendezés elemeinek patronnal megvalósított hevítése (Kim et al., 2008). Az FLD felvételének első lépésében a ráncgátlógyürük összezárnak, ezzel egy bordát alakítva a lemezbe. Az anyag hőmérsékletének növekedése először ezen a külső gyürün kezdődik meg. Mivel ilyenkor az alakítást végző bélyeg, még csak egy pontban érintkezik a lemezzel, a darab vizsgálati részének hőmérséklete nem emelkedik a megfelelő szintre. $\mathrm{Az}$ alakítás megkezdése után a próbatest deformációjának következtében a bélyeg hőátadása emelkedik, mivel az anyag nagyobb felületen érintkezik azzal. Ebben az esetben a hőátadás két egymástól eltérö pontban indul meg a vizsgálati felületen. A bélyeg és a borda közötti körgyürün - amely nagy valószínüséggel a szakadás felülete is egyben - nehezen állítható be az tökéletes hömérséklet. Ha a próbatestet az SHT hőmérsékletre külön kemencében hevítjük és elöhevített szerszámelemek között végezzük el a vizsgálatot, akkor pontosabb, megbízható eredményeket kaphatunk, de a levegő hőelvonása így is inhomogén hőmérsékletmezőt eredményez.

\section{4. Összefoglalás, következtetések}

Napjaink autóipari fejlesztéseinek a legnagyobb hajtóereje a károsanyag kibocsátás tekintetében kitüzött célok elérése 2030-ra. A tömegredukció megvalósításához alkalmazott nagy szilárdságú acélok elértek egy határt mely lekorlátozza azok alkalmazhatóságát. Ezért fordultak a fejlesztők az alumíniumok felé, melyeknek sürüsége -így tömege- jelentősen kisebb, mint az acéloknak. A korszerü nagyszilárdságú alumíniumok alakítására azonban új, eddig nem alkalmazott módszereket kellett kifejleszteni, amik napjainkban még csak kísérleti fázisban müködnek. Ahhoz, hogy az új technológiákat alkalmazni tudjuk a mindennapi gyártás folyamán elsősorban szükség lenne arra, hogy a célorientált szimulációs programok alkalmasak legyenek e folyamatok szimulációira. Ezek jellemzően három anyagparaméter alapján modellezik az egyes alakítási folyamatokat. Az első ilyen anyagparaméter a folyási görbe, amelynek felvétele meleg alakítás esetén nem egyszerủ, de megoldható, illetve különböző módszerekkel a programba iktatható. Mivel a folyási határfelület számítása az előbb említett folyási görbéken alapul, ezek kezelését is megoldottnak tekinthetjük HFQ folyamatoknál.

$\mathrm{Az}$ alakítási határfelület illetve az alakítási határgörbe, több paramétertöl függő anyagparaméter, amelyek alkalmazása még nem megoldott és ez komoly gondot jelent. Ezek a görbék adják meg a legegyszerübb, legközérthetőbb módon azt, hogy a lemez hol fog károsodni, illetve mikor fog a nem megengedett értékben elvékonyodni. Paraméterfüggöségük miatt nem alkalmazhatók károsodási határesetek definiálására. Az alakítási határállapot meghatározásának vannak újabb a károsodáshalmozódás elvére épülő modelljei, de ezeknek a mindennapok iparában 
alkalmazott célszoftverekbe való beillesztése komoly müszaki és technológiai kihívások elé állítják az autóiparban tevékenykedő fejlesztőmérnököket a 21. században.

\section{Irodalomjegyzék}

AutoForm Engineering GmbH: AutoForm ${ }^{\text {plus }} \mathrm{R6}$

Climate Action (2016): Implementing the Paris Agreement Progress of the EU towards the at least $40 \%$ target. Progress Report. Brussels 08.11.2016

Fakir, O. E., Wang, L., Balint, D., Dear. J. P., Lin, J., Dean, T. A. (2014): ABAQUS-VUMAT CDM. Gao, H. (2017): Study of HFQ Forming Process on Lightweight alloy Component.

ISO 12 204-1:2008 Metallic materials: Sheet and strip, Determination of forminglimit curves, Part 1: Measurement and application of forming-limit diagrams in the press shop. International Organization for Standardization

Kim, H. J., Choi, S. Ch., Lee, K. T., Kim, H. Y. (2008): Experimental Determination of Forming Limit Diagram and Springback Characteristics of AZ31B Mg Alloy Sheets at Elevated Temperatures. Materials Transactions, 49 (5): 1112-1119.

Kovács P. Z. (2012): Alakítási határdiagramok kísérleti és elméleti elemzése. PhD értekezés. Miskolci Egyetem, Miskolc.

Lukács Zs. (2014): Nagyszilárdságú acélok visszarugózásának modellezése és kísérleti meghatározása. PhD értekezés. Miskolci Egyetem, Miskolc.

Manach, P., Coer, J., Jégat, A., Laurent H., Yoon J. (2016): Benchmark 3 - Springback of an Al-Mg alloy in warm forming conditions, Journal of Physics: Conference Series; 734 (2): 1.

Mohamed, M., Lin. J., Foster, A., Dean, T., Dear, J. (2014): New test design for assessing formability of materials in hot stamping. ICTP 2014. október 19-24., Nagoya, Japán, Procedia Engineering, (81):1689-1694.

Nan, L., Zhutao, S., Jianguo, L., Dean, T. (2016): Investigation of Uniaxial Tensile Properties of AA6082 under HFQ® Conditions. Key Engineering Materials, 716: 337-344.

Raugei, M, Fakir, O. E., Wang, L., Lin, J., Morrey, D. (2014): Life cycle assessment of the potential environmental benefits of a novel hot forming process in automotive manufacturing . Journal of Cleaner Production, 83: 80-86.

Shao Z., Bai, Q., Li, N., Lin, J., Shi, Z., Stanton, M., Watson, D.,. Dean, T. A (2016): Experimental investigation of forming limit curves and deformation features in warm forming of an aluminium alloy. Proceedings of the Institution of Mechanical Engineers, Part B: Journal of Engineering Manufacture, 10.1177/0954405416645776.

Wang, L., Strangwood, M., Balint, D., Lin, J., Dean, T. A. (2008): A process in forming high strength and complex-shaped Al-alloy sheet components. In: British Patent, vol WO2008059242, UK

Zhang, C., Bellet, M., Bobadilla, M., Shen, H., Liu, B. (2010): A Coupled Electrical - Thermal Mechanical Modeling of Gleeble Tensile Tests for Ultra-High-Strength (UHS) Steel at a High Temperature. Metallurgical And Materials Transactions A, 41 (9): 2304-2317. 